\title{
10
}

\section{Towards a Ladder of Marine/Maritime Spatial Planning Participation}

\author{
Andrea Morf, Michael Kull, Joanna Piwowarczyk, \\ and Kira Gee
}

\section{Introduction: Why Participation and How Much}

Marine/maritime spatial planning (MSP) is increasingly popular as an approach to address conflicts of use in the marine environment and to promote environmental sustainability and blue growth. How and why to involve marine users and society at large is a topic of debate among researchers (see also Chaps. 8, 9 and 13 in this book), but also a concern for practitioners and decision-makers tasked with implementing MSP.

A. Morf (州)

Swedish Institute for the Marine Environment, University of Gothenburg,

Gothenburg, Sweden

Nordregio, Stockholm, Sweden

e-mail: andrea.morf@gu.se

M. Kull

Nordregio, Stockholm, Sweden

J. Piwowarczyk

Institute of Oceanology, Polish Academy of Sciences, Sopot, Poland

K. Gee

Human Dimensions of Coastal Areas, Helmholtz Zentrum Geesthacht, Geesthacht, Schleswig-Holstein, Germany 
Policy documents, such as e.g. global guidelines by the Intergovernmental Oceanographic Commission (IOC) ${ }^{1}$, by the European Union (EU), ${ }^{2}$ and national legislation, require the involvement of stakeholders and civil society in MSP. This resonates with a larger scale paradigm shift of the last decades from government to governance, understood here as the involvement of societal actors, in various related fields including planning (e.g. Stoker 1998; Selle 1996; Fainstein and Fainstein 1996; Sandercock 1998). Nature conservation and natural resource and environmental management have witnessed a similar shift, expressed for example in the discussion on co-management, Agenda 21, Integrated Coastal Zone Management or the Ecosystem Approach (e.g. Borrini-Feyerabend et al. 2004; NRC 2008). In recent years, a wide range of guidelines on stakeholder involvement in MSP has become available, often resulting from European projects on $\mathrm{MSP}^{3}{ }^{3}$ which emphasise stakeholder involvement and technical advice as a key to success. However, very few of these project-based documents provide advice that is directly applicable in the more statutory contexts in which MSP in implemented.

Despite the generally greater routine in public participation (Quick and Bryson 2016; Bryson et al. 2012; Bingham et al. 2005), the principles and methods employed across countries and settings vary considerably. Participation can be seen as a discrete act or a set of practices with different elements, tools and methods used (Quick and Bryson 2016) and can be understood as simple provision of information, or deliberation or collaborative decision-making. Expected outcomes and benefits of participation are also diverse, ranging from more principled benefits (e.g. improving the legitimacy of decisions) to more practical benefits (e.g. improving the knowledge base for decisions), as well as efficiency gains (e.g. participation in conflict prevention). At a more theoretical level, the growing practice of participation has given rise to questions regarding the legitimacy and usefulness of participation, representation and inclusion and the nature and role of different kinds of knowledge and expertise. There are recognised challenges in designing

\footnotetext{
${ }^{1}$ See: http://msp.ioc-unesco.org/ and http://msp.ioc-unesco.org/msp-guides/msp-guides-overview/.

${ }^{2}$ EU Directive 2014/89/EU: "Member States shall establish means of public participation by informing all interested parties and by consulting the relevant stakeholders and authorities, and the public concerned, at an early stage in the development of maritime spatial plans, in accordance with relevant provisions established in Union legislation." (Article 9, Directive 2014/89/EU, our emphasis).

${ }^{3}$ See, for example, EU policy initiatives on integrated coastal management and MSP (EC 2002; EC 2014), EU financed MSP projects including a focus on stakeholder involvement (e.g. PartiSEApate, Baltic SCOPE, Pan-Baltic SCOPE, SIMCelt, Transboundary Planning in the European Atlantic (TPEA)), and the 2018 MSP workshop in Brussels and for the Baltic the HELCOM-VASAB MSP principles and guidelines (2010 and 2016).
} 
participatory processes "well adapted to their context" (Quick and Bryson 2016, see also Chap. 13 in this book).

Arguably, MSP is a particularly complex context for participation both conceptually and practically. MSP is dealing with what is known as "wicked" problems (Rittel and Webber 1973). These are characterised by multiple dimensions, cross-boundary issues and ongoing change both in the natural environment and in the social sphere. This results in the need to take legitimate decisions within a context of high uncertainty and value conflicts (e.g. Jentoft and Chuenpagdee 2009). But although meaningful participation is a core requirement for MSP, it also needs to be effective, as it is costly in time and an effort for both planners and participants.

Presently, institutional systems and practice for MSP are evolving rapidly but unevenly (Kull et al. 2017; Janßen et al. 2018). Given the need to develop more participatory forms of MSP, it is therefore necessary to outline different degrees of participation to see what could, and possibly is being achieved in practice. This particularly applies to the transboundary context within which MSP is mostly taking place.

This chapter develops a structure for practitioners and researchers to systematically reflect on participation in MSP in transboundary contexts. It is based on the metaphor of "ladders of participation", which is broadly used to conceptualise and evaluate different degrees of participation. First, we analyse relevant ladders with the aim to extract key dimensions of participation for MSP. We then present current challenges of stakeholder involvement in MSP, using recent research from the Baltic Sea area from the projects BaltSpace (Morf et al. forthcoming) and Baltic SCOPE (Kull et al. 2017). Section 4 develops a ladder-based conceptual framework that could help assess to what degree various ambitions of participation are being achieved. We then conclude how the ladder could be developed further to assist a more systematic evaluation and learning for developing participation in cross-border MSP.

\section{Ladders of Participation and Their Relevance for MSP}

\subsection{Examples of Ladder Metaphors}

During almost five decades, scholars and practitioners in various fields have used ladders, stairways and other metaphors to describe and assess the degree of power sharing, interaction and inclusiveness in planning and environmental 
management. Following on from the classic example of Arnstein (1969), the concept has also been applied to MSP, such as the ladder by Kidd and McGowan (2013) or the PartiSEApate handbook (Matczak et al. 2014) to characterise the intensity of transboundary collaboration. Reed (2008, p. 2419), analysing participation typologies in environmental management, distinguishes four types of approaches to analysing participation based on the following dimensions:

a. different degrees of participation on a continuum (ladder types);

b. the nature of participation, identified by the direction of communication flows;

c. theory, distinguishing between normative and/or pragmatic participation; and

d. the objectives of participation (e.g. research or development-driven, planner or people-centred, diagnostic and learning-centred).

In order to identify suitable starting points for MSP, we review a selection of relevant ladders and related metaphors (Table 10.1), highlighting their conceptual development over time. Our selection focuses mostly on types (a) and (b), but not exclusively so. The table contains a short description of the ladders, extracting key dimensions that also seem important for MSP.

Our chosen starting point in the chronological list is the ladder by Arnstein (1969), which laid the groundwork for many later ladders or similar metaphors. It considers participation mostly from the perspective of power and interaction, starting from what can be called the "dark" side of planning, ascending towards increasing inclusion. The most basic distinctions are nonparticipation (unable to have a say but being treated or even manipulated into something), tokenism (receiving something but not necessarily exerting influence, described as informing, consulting, placation) and citizen power (implying real influence, by inclusion in a partnership, having power delegated or being in full control). One problem is that Arnstein's ladder appears to be one-dimensional, but it actually blends the power dimension with methods and functions of participation as well as a value judgement, considering the higher steps on the ladder more desirable. The "dark" side may also be overemphasised: information and consultation may in fact be a more neutral way of interaction between authorities and citizens rather than necessarily tokenistic.

The perspective of power and the ability to influence decisions has remained central in subsequent ladders such as those of Pretty (1995) and Selle (1996). Selle uses the metaphor of a stairway of participation in planning, where the 
Table 10.1 Participation ladders and related metaphors and important dimensions raised

\begin{tabular}{|c|c|c|}
\hline $\begin{array}{l}\text { Author, } \\
\text { title/ } \\
\text { metaphor }\end{array}$ & Main content & Key dimensions of participation raised \\
\hline Ladders & Urban / land planning & \\
\hline $\begin{array}{l}\text { Arnstein } \\
1969 \\
\text { "A Ladder of } \\
\text { Citizen } \\
\text { Participation" }\end{array}$ & $\begin{array}{l}\text { "Classic" ladder with eight rungs ranging } \\
\text { from two types of non-participation (1. } \\
\text { manipulation, 2. therapy), to graded } \\
\text { tokenism (3. informing, 4. consultation, } 5 . \\
\text { placation), to three degrees of citizen } \\
\text { power (6. partnership, 7. delegated power, } \\
\text { 8. citizen control) (our numbering). }\end{array}$ & $\begin{array}{l}\text { - Power: unequally distributed in planning. } \\
\text { - Need to empower and include citizens in } \\
\text { planning. } \\
\text { - Forms of participation (including valuation). } \\
\text { - Dark side and misuse of participation } \\
\text { processes (placation, manipulation, } \\
\text { tokenism). }\end{array}$ \\
\hline \multirow[t]{2}{*}{$\begin{array}{l}\text { Selle } 1996 \\
\text { Stairway of } \\
\text { participation } \\
\text { in planning }\end{array}$} & $\begin{array}{l}\text { Stairway of four steps building on each other, } \\
\text { also mirroring a shift in participation } \\
\text { paradigms over decades: } \\
\text { 1. Information of affected (1960s); } \\
\text { 2. Information of general public (1970s); } \\
\text { 3. Activating participation (1980s); } \\
\text { 4. Collaborative participation (1990s). }\end{array}$ & $\begin{array}{l}\text { - Purposes of participation. } \\
\text { - Degrees and forms of involvement in terms } \\
\text { of power sharing. } \\
\text { - Complementary steps: all steps are } \\
\text { necessary, may differ in terms of target } \\
\text { group and timing during a planning process. } \\
\text { - Development over time and paradigm shift. }\end{array}$ \\
\hline & Development & \\
\hline $\begin{array}{l}\text { Pretty } 1995 \\
\text { "A Typology } \\
\text { of partici- } \\
\text { pation: } \\
\text { How people } \\
\text { participate in } \\
\text { development } \\
\text { programs } \\
\text { and } \\
\text { projects" }\end{array}$ & $\begin{array}{l}\text { Seven degrees of people's involvement in } \\
\text { development project work: } \\
\text { 1. Manipulative participation (pretence); } \\
\text { 2. Passive participation (being told what has } \\
\text { been decided or already happened); } \\
\text { 3. Participation by consultation; } \\
\text { 4. Participation for material incentives } \\
\text { (content decided externally); } \\
\text { 5. Functional participation (interactive, } \\
\text { shared decision-making, but major } \\
\text { decisions already taken externally); } \\
\text { 6. Interactive participation (joint analysis, } \\
\text { participation as a right and not just a means } \\
\text { to achieving project goals, more control over } \\
\text { resources and outcomes); } \\
\text { 7. Self-mobilisation (initiative independent } \\
\text { from external institutions, taking advice, full } \\
\text { control over use of resources). }\end{array}$ & $\begin{array}{l}\text { - Power and purposes of participation } \\
\text { - Roles and activities } \\
\text { - Local knowledge } \\
\text { - Power and empowerment }\end{array}$ \\
\hline $\begin{array}{l}\text { Beyond } \\
\text { simple } \\
\text { ladders }\end{array}$ & Climate change adaptation & \\
\hline $\begin{array}{l}\text { Collins \& } \\
\text { Ison } 2009 \\
\text { "Jumping off } \\
\text { Arnstein's } \\
\text { ladder: } \\
\text { Social } \\
\text { Learning as } \\
\text { new policy } \\
\text { paradigm" }\end{array}$ & $\begin{array}{l}\text { Four embedded ovoids connected in one } \\
\text { place instead of a ladder from smaller } \\
\text { innermost to larger encompassing: } \\
\text { 1. Information } \\
\text { 2. Consultation } \\
\text { 3. Participation } \\
\text { 4. Social learning. } \\
\text { (our numbering) }\end{array}$ & $\begin{array}{l}\text { - (Social) learning: need to think in terms of } \\
\text { open communication and learning of larger } \\
\text { groups, governance systems or whole } \\
\text { societies. } \\
\text { - Participation is not just about more power } \\
\text { and authority. } \\
\text { - No linear relation or hierarchy between } \\
\text { levels of participation. } \\
\text { - Change over time of policy problems, roles } \\
\text { and responsibilities, requiring flexible } \\
\text { structures and learning processes. }\end{array}$ \\
\hline
\end{tabular}


Table 10.1 (continued)

\begin{tabular}{|c|c|c|}
\hline $\begin{array}{l}\text { Merging and } \\
\text { meeting } \\
\text { ladders }\end{array}$ & Natural resource management \& planning & \\
\hline $\begin{array}{l}\text { Berkes } 1994 \\
\text { Levels of co- } \\
\text { management } \\
\text { in fisheries } \\
\text { Pomeroy \& } \\
\text { Berkes } 1997 \\
\text { "A hierarchy } \\
\text { of co-mana- } \\
\text { gement } \\
\text { arrangements" } \\
\text { Carlsson \& } \\
\text { Berkes 2005 } \\
\text { Berkes 2009 } \\
\text { "Evolution of } \\
\text { co- } \\
\text { management: } \\
\text { the role of } \\
\text { knowledge } \\
\text { generation, } \\
\text { bridging } \\
\text { organisations } \\
\text { and social } \\
\text { learning" }\end{array}$ & $\begin{array}{l}\text { Seven levels of co-management (from } \\
\text { bottom to top, our numbering): } \\
\text { 1. Informing (community informed about } \\
\text { decisions already made); } \\
\text { 2. Consultation (start of face-to-face } \\
\text { contact, community input heard, but not } \\
\text { necessarily heeded); } \\
\text { 3. Co-operation (community starts to have } \\
\text { input into management, e.g. use of local } \\
\text { knowledge, research assistants); } \\
\text { 4. Communication (start of two-way } \\
\text { information exchange; local concerns begin } \\
\text { to enter management plans), (divided in } \\
\text { two in Pomeroy \& Berkes 1997: } \\
\text { 4. Communication, 5. Information exchange) } \\
\text { 5.(6) Advisory Committees (partnership in } \\
\text { decision-making starts; joint action on } \\
\text { common objectives); } \\
\text { 6. (7) Management Boards (community is } \\
\text { given opportunity to participate in } \\
\text { developing and implementing management } \\
\text { plans); } \\
\text { 7. (8) Partnership/Community Control } \\
\text { (partnership of equals; joint decision- } \\
\text { making institutionalised, power delegated } \\
\text { to community where feasible); } \\
\text { 9. Inter-area coordination (geographical } \\
\text { expansion) (Pomeroy \& Berkes 1997) }\end{array}$ & $\begin{array}{l}\text { - Rights and roles (decision, use, ownership) } \\
\text { in relation to sustainable resource } \\
\text { management: multiple forms of graded } \\
\text { property and use rights in relation to natural } \\
\text { resources, including communal } \\
\text { management. } \\
\text { - Local and scientific knowledge need to be } \\
\text { combined for efficient management. } \\
\text { - Need for central government-based and } \\
\text { community-based resource management to } \\
\text { meet and interact (delegation, self- } \\
\text { management). Both can need each other - } \\
\text { for various reasons (support, knowledge, } \\
\text { acceptance, legitimacy, long-term } \\
\text { commitment to sustainable resource use). } \\
\text { - Embedded systems of management require } \\
\text { organisational cross-communication } \\
\text { (Carlsson \& Berkes } 2005 \text { ): exchange system - } \\
\text { joint organisations - nested system. } \\
\text { - Turn to adaptive co-management after } 2008 \\
\text { adds a time and larger scale learning } \\
\text { dimension, with emphasis on knowledge } \\
\text { generation and exchange, individual and } \\
\text { organisational and social learning, evolving } \\
\text { management arrangements and adaptive } \\
\text { management (Berkes 2009). }\end{array}$ \\
\hline $\begin{array}{l}\text { Hurlbert \& } \\
\text { Gupta } 2015 \\
\text { "The split } \\
\text { ladder of } \\
\text { participation" } \\
\text { see Fig. } 1\end{array}$ & $\begin{array}{l}\text { A split, X or H-shaped ladder with the two } \\
\text { rungs of information and consultation (inclu- } \\
\text { ding testing of ideas and seeking advice) as } \\
\text { connecting middle rungs. Arnstein's ladder } \\
\text { is extended, using a clear analytical } \\
\text { structure. The ladder is formed around four } \\
\text { logically connected main dimensions: } \\
\text { a. the type of problems to be addressed in } \\
\text { relation to agreement on values and } \\
\text { agreement/certainty on knowledge, } \\
\text { b. the level of learning needed, } \\
\text { c. the level of trust, and } \\
\text { d. the level of power sharing (management } \\
\text { or governance). } \\
\text { The ladder extends upward over 8-9 } \\
\text { degrees of power sharing and left and right } \\
\text { in relation to the level of trust and problem } \\
\text { solving. The lower rungs indicate low } \\
\text { participation, the higher ones high } \\
\text { participation. The left side implies low trust } \\
\text { and low problem solving and the right side } \\
\text { high trust and problem solving. } \\
\text { For details, see Fig. } 10.1 \text { and text. }\end{array}$ & $\begin{array}{l}\text { - Level of power sharing (steps of ladder/from } \\
\text { management to governance): Arnstein's } \\
\text { original ladder lies across within moderately } \\
\text { structured problems: the lower end on the } \\
\text { low-trust side with zero-loop learning and } \\
\text { low problem-solving and the higher end on } \\
\text { high-trust side with double-loop learning } \\
\text { and high problem-solving. } \\
\text { - Type of policy problems. MSP development } \\
\text { at present and strategic MSP problems } \\
\text { reside most likely in the quadrants three } \\
\text { and four, implying disagreement in } \\
\text { knowledge and values. } \\
\text { - Nature of learning in relation to the } \\
\text { problems, from zero to triple-loop learning, } \\
\text { requires adaptive management/governance. } \\
\text { - Trust is important and related to interaction } \\
\text { and learning. }\end{array}$ \\
\hline
\end{tabular}


Table 10.1 (continued)

\begin{tabular}{|c|c|c|}
\hline Ladders of & Marine spatial planning & \\
\hline $\begin{array}{l}\text { Kidd \& } \\
\text { McGowan } \\
2013 \\
\text { "A ladder of } \\
\text { transnationa } \\
\text { I partnership } \\
\text { working to } \\
\text { support } \\
\text { MSP" }\end{array}$ & $\begin{array}{l}\text { The first MSP specific ladder, focusing on } \\
\text { collaboration across borders and its degree } \\
\text { of institutionalisation: from less formalised } \\
\text { (bottom) to increasingly institutionalised } \\
\text { (top). From bottom (our numbering): } \\
\text { 1. Information sharing (building trust, } \\
\text { understanding and capacity); } \\
\text { 2. Administration sharing (creating } \\
\text { collaborative advantages); } \\
\text { 3. Agreed joint rules (constituting shared } \\
\text { rule systems); } \\
\text { 4. Combined organisation (changing the } \\
\text { institutional order); } \\
\text { 5. Combined constitution (changing the } \\
\text { political order). }\end{array}$ & $\begin{array}{l}\text { - Reflection on different dimensions: power, } \\
\text { partnerships, process of development (and } \\
\text { need of adaptation), relative formality (less } \\
\text { formal as less aggressive). } \\
\text { - Emphasising development of partnerships } \\
\text { over time: degree of active interaction and } \\
\text { delegation of responsibilities for this } \\
\text { purpose to specific organisations. } \\
\text { - Emphasising the need for a mix of different } \\
\text { stakeholders to interact (including mandated } \\
\text { authorities), focusing on organised actors. } \\
\text { - Focus on transboundary collaboration and } \\
\text { development of organised multi level multi- } \\
\text { actor partnerships supporting MSP, less on } \\
\text { formally required MSP participation. }\end{array}$ \\
\hline $\begin{array}{l}\text { Twomey \& } \\
\text { O'Mahony, } \\
2018 \\
\text { Continuum } \\
\text { of } \\
\text { Stakeholder } \\
\text { Participation } \\
\text { in European } \\
\text { MSP }\end{array}$ & $\begin{array}{l}\text { Four levels of participation (our numbers) } \\
\text { on a reversed ladder including a triangle } \\
\text { figure to represent main actor types } \\
\text { (government on top, industry and civil society } \\
\text { on the bottom) and connecting arrows: } \\
\text { 1. Informing and awareness raising without } \\
\text { feedback (one-way process/top- } \\
\text { down/arrows down). } \\
\text { 2. Consultation providing feedback through } \\
\text { statutory process (one-way process/top- } \\
\text { down/arrows go up). } \\
\text { 3. Stakeholder engagement working } \\
\text { directly with government (two-way } \\
\text { dialogue/top-down/arrows both ways). } \\
\text { 4. Stakeholder collaboration (multi-sector } \\
\text { dialogue/blend of top-down and bottom- } \\
\text { up/arrows both ways in triangle) implying } \\
\text { partnering with government. }\end{array}$ & $\begin{array}{l}\text { - Focus is on power sharing and on dialogue } \\
\text { and interaction between different parts of } \\
\text { society (Government, Industry \& Civil } \\
\text { Society). } \\
\text { - A continuum is more likely than ladder. All } \\
\text { types of interactions may be needed and } \\
\text { build on each other. } \\
\text { - Combining and clarifying dimensions } \\
\text { through triangles (who interacts with } \\
\text { whom), direction of interaction (arrows), } \\
\text { quality of interaction (text). } \\
\text { - Need to combine top-down and bottom-up } \\
\text { with users but also cross-level among } \\
\text { authorities. } \\
\text { - Does not address cross-border aspects and } \\
\text { mandated key stakeholders (those with } \\
\text { more strongly defined formal rights), and } \\
\text { timing only to some extent. }\end{array}$ \\
\hline
\end{tabular}

bottom steps of information and consultation are seen as complementary and rights based. He also suggests that citizen participation has developed over time towards increasingly inclusive and interactive forms, while the bottom steps remain significant as a base. Collins and Ison (2009) add the dimension of learning, emphasising the need to think in terms of non-linear power and open communication and learning in larger groups and whole societies.

The natural resource co-management discourse adds further important dimensions to the ladders (e.g. Berkes 1994) from the perspective of user rights and functions of participation. Their point of departure differs slightly and grounds in natural resources and ecosystems. They also highlight the knowledge dimension, referring to different types of knowledge situated with science and authorities and resource users that need to meet and learning through adaptive co-management (Armitage et al. 2008). 
Moving towards more recent examples in Table 10.1, ladder metaphors gradually become more sophisticated as further dimensions are recognised and specified. An important insight is that there is no linear progression between different levels of power. Citizen control, for example, is not necessarily the highest goal, as policy problems change and may require different levels of participation (Bishop and Davis 2002). Furthermore, as highlighted by Collins and Ison (2009), roles and responsibilities — and with them, degrees of power-are not absolute but may change during the participation process. Power is relational (Dyrberg 1997), circulating through all actors rather than distributed in a linear, hierarchical and one-directional manner (Foucault 1980). These aspects are also important in the context of MSP (see Sect. 4).

A particularly interesting recent ladder of participation is the "split ladder of participation", developed by Hurlbert and Gupta (2015) (see Fig. 10.1). Its attraction lies in its multidimensionality, bringing together many dimensions developed in earlier ladders, including power sharing, problem structure and learning. The ladder consists of four quadrants and four "pull factors". The lower quadrants (1 and 2) imply low participation and adaptive management, the higher ones (3 and 4) high participation and adaptive governance. The left-hand quadrants represent low trust and problem-solving capacity, the right-hand quadrants high trust and problem-solving capacity. Each quadrant is further

\begin{tabular}{|c|c|c|}
\hline $\begin{array}{l}\text { Low trust } \\
\text { Low problem solving }\end{array}$ & & $\begin{array}{l}\text { High trust } \\
\text { High problem solving }\end{array}$ \\
\hline $\begin{array}{l}\text { Quadrant } 4 \\
\text { Unstructured problems } \\
\text { Dialogue and discourse } \\
\text { Triple loop learning }\end{array}$ & $\begin{array}{l}\text { High participation } \\
\text { Adaptive Governance }\end{array}$ & $\begin{array}{r}\text { Quadrant } 3 \\
\text { Moderately structured problems } \\
\text { Values or science } \\
\text { Double loop learning }\end{array}$ \\
\hline & & 9. Self management \\
\hline 8. Consensus may be out of reach & & 8. Achieve consensus \\
\hline 7. Debate on different values & & 7. Seek consensus \\
\hline 6. Discuss different perspectives & & 6. Increasing citizen power \\
\hline $\begin{array}{l}\text { Low trust } \\
\text { Low problem solving }\end{array}$ & $\begin{array}{l}\text { 5. Consult, test ideas, seek advice } \\
\text { 4. Information }\end{array}$ & $\begin{array}{r}\text { High trust } \\
\longrightarrow \quad \text { High problem solving }\end{array}$ \\
\hline 3. Placation & & 3. Educate (by experts) \\
\hline 2. Therapy & & 2. Delegated power (to experts) \\
\hline 1. Manipulation & $\downarrow$ & 1. Take decisions (by experts) \\
\hline $\begin{array}{l}\text { Moderately structured problems } \\
\text { Values or science } \\
\text { Zero loop learning } \\
\text { Quadrant } \mathbf{1}\end{array}$ & $\begin{array}{c}\text { Low Participation } \\
\text { Adaptive Management }\end{array}$ & $\begin{array}{r}\text { Structured problems } \\
\text { Technocratic policy making } \\
\text { Single loop learning } \\
\text { Quadrant 2 }\end{array}$ \\
\hline
\end{tabular}

Fig. 10.1 The split ladder of participation (Source: Hurlbert and Gupta 2015, p. 105, adapted) 
defined by the structure of problems, dialogue and discourse, and types of learning. The force of the arrows thus pulls the ladder apart into specific expressions of participation. We illustrate the quadrants with examples from MSP.

1. The lower left-hand quadrant covers moderately structured problems with disagreement on values or knowledge, low trust and zero-loop learning of both planners and society. This results in low problem-solving, described in the ladder as manipulation, placation and information. Examples could be controversial top-down planning of risk-filled infrastructure or "old style" conservation and resource management meeting resistance with resource users (e.g. fishers).

2. The lower right-hand quadrant covers structured problems (implying agreement on problems and solutions) and technocratic policymaking, with high trust and single-loop learning. This results in little participation but a high capacity in expert-led problem-solving (educate, delegated power, take decisions). Examples could be construction permits with moderate negative impacts, in situations without major value conflicts, where standard procedures work well, so decisions can in fact be delegated to experts, implying single loop learning in content by experts and public.

3. The higher right-hand quadrant encompasses moderately structured problems (implying disagreement on values or knowledge), high levels of trust and double-loop learning. This results in high problem-solving capacity (consult, test ideas, seek advice, increase citizen power, seek consensus, achieve consensus, self-management). Examples are comprehensive marine or coastal planning with value conflicts, adaptive co-management and community-based resource management. Double loop learning by questioning basic values and goals may be needed to address inherent conflicts.

4. The higher left-hand quadrant contains the unstructured problems (implying high disagreement with respect to knowledge and values), low trust and a need for triple-loop learning. This results in low problem-solving capacity, with the rungs of consulting, testing ideas and seeking advice the same as in the previous quadrant, but consensus here may be out of reach. Examples here are how to adapt coasts to climate change, including uses that are not yet well established in MSP and whose consequences are still unknown, and possibly also cross-border planning. Presently, triple loop learning through reflection about the process and inherent learning is highly necessary and apparently under way, especially in transboundary MSP. 


\subsection{Elements with Relevance to MSP}

From the ladders and metaphors presented, we consider the following to represent key dimensions in analysing and discussing participation in MSP:

- Problem type and related learning: dealing with more or less wicked problems with knowledge gaps and value conflicts, requiring more or less direct interaction and learning across sectors and levels by individuals, groups, organisations and societies (Collins \& Ison)—from zero- to double- to triple-loop learning depending on the type of problems to be addressed (Hurlbert \& Gupta).

- Trust as promoted by the quality of the process in terms of openness, transparency, legitimacy (ibid.) and the need to interact between different groups (Twomey and O'Mahony 2018).

- The degree of power sharing between those in charge (all ladders) and those participating, depending on roles which may change over time (comanagement discourse).

- Functions and objectives of participation (co-management discourse).

Important dimensions that are not captured sufficiently in the above and need to be added to the metaphors are:

- the timing of participation at different stages of MSP and

- the spatial context of participation: local, national, transboundary or crosscutting (Kidd \& McGowan). This aspect is particularly important in transboundary settings where cross-border participation may be required.

The following section illustrates the importance of these dimensions by referring to the Baltic Sea perspective.

\section{Participation in Transboundary MSP: Conditions and Challenges in the Baltic Sea}

The Baltic Sea region (BSR) can be seen as pioneering in institutionalising high level cross-border collaboration on the environment (Helsinki Commission $[\mathrm{HELCOM}]^{4}$ ) and planning (Vision and Strategies Around the

\footnotetext{
${ }^{4}$ HELCOM (Baltic Marine Environment Protection Commission-Helsinki Commission) is the governing body of the Convention on the Protection of the Marine Environment of the Baltic Sea Area (www.helcom.fi).
} 
Baltic Sea $[\mathrm{VASAB}]^{5}$ ), including a common MSP Working Group (cf. Kidd and McGowan 2013; Zaucha 2014a). The last decade has seen a chain of transdisciplinary cross-border research and development projects on MSP in the BSR (for a summary, see Zaucha 2014b), where scientists and practitioners have been working together to understand problems and develop practice. A rapid process of institutionalisation of MSP is under way, driven both by planning and coordination needs and the EU's MSP Directive (Zaucha 2014a); this encompasses countries at very different stages of MSP development.

In relation to participation, two out of ten soft-law joint HELCOMVASAB MSP principles refer to public participation: (1) Principle 5: Participation and Transparency and (2) Principle 7: Transnational coordination and consultation (HELCOM-VASAB MSP WG 2010). Principle 5 states that relevant authorities and stakeholders, including coastal municipalities and national and regional bodies, should be involved in MSP initiatives as early as possible and that public participation should be secured. Principle 7 calls for a Baltic Sea perspective in MSP, pan-Baltic dialogue in developing maritime spatial plans and consultation between the BSR countries and the EU (HELCOM-VASAB MSP WG 2010, our emphasis). The related guideline on transboundary consultations, public participation and co-operation (HELCOM-VASAB n.d.) specifies a number of principles departing mainly from an instrumental perspective on participation. Public participation-as defined by these guidelines - should aim to increase quality and acceptance of the public decisions and reduce tensions and disputes over the marine space and marine resources (HELCOM-VASAB n.d.).

However, when translating such general principles into concrete policy processes for the BSR, it becomes apparent that concepts such as "stakeholder", "participation" and "MSP" might not mean the same in each country (Kull et al. 2017). Moreover, the awareness of related problems may vary between countries, sectors and levels (Kull et al. 2017; Morf et al. forthcoming). Although collaboration in the BSR scores high on the collaboration ladder by Kidd and McGowan (2013), stakeholder involvement on a pan-Baltic level has so far tended to be formalist, and it can be difficult for new stakeholders to enter the process (Janßen et al. 2018).

Based on Janßen et al. (2018), Kull et al. (2017), and Morf et al. (forthcoming), the major obstacles and challenges in stakeholder involvement across borders in the BSR include:

\footnotetext{
${ }^{5}$ VASAB (Visions And Strategies Around the Baltic Sea) is an intergovernmental multilateral co-operation of 11 countries of the Baltic Sea Region in spatial planning and development (www.vasab.org).
} 
1. Differences in design for participation and in understanding of stakeholders' engagement across borders. Institutional differences concerning roles and responsibilities in MSP are important when there is a need to collaborate with corresponding authorities or other stakeholders in another juridical system. Both planners and participants need to recognise how MSP operates in the other country, who to ask for information and how to contact a particular type of stakeholder. Governance structures for implementing MSP in the BSR countries vary both vertically (what level of governance is responsible for MSP) and horizontally (what thematic agency or ministry is responsible ${ }^{6}$. Moreover, learning about MSP in other countries takes time and requires financial and other resources. Last but not least, building trust between parties in various countries takes time too.

2. Limited time and resources of both planners and participants. Stakeholder participation is usually a lengthy process, and it can be difficult to keep participants engaged. The main challenges on the participants' side are loss of interest (especially if participation in MSP is not considered beneficial initially) and limited personnel and funds. On the planners' side, time and resources are often not available to develop frameworks to support transboundary collaboration and create the networks between planners and other civil servants. Moreover, language differences can impact the process in terms of costs and time (translation and interpretation).

3. Different timing and time horizons for MSP across borders. MSP is not synchronised across borders, which impacts stakeholders' awareness and motivation to participate. For example, stakeholders in a country where the process has just started might not have enough knowledge and capacity to meaningfully participate in cross-border proceedings, compared to stakeholders in a country with a more advanced process.

4. Stakeholders' understanding of MSP and their roles in MSP. MSP is still a new process and many potential stakeholders are unaware of clear benefits of involvement. There are few capacity-building initiatives to facilitate and empower meaningful stakeholder participation. Stakeholders may have wrong expectations of MSP, risking disappointment in the process, its legitimacy and outcomes.

\footnotetext{
${ }^{6}$ In Latvia MSP is supervised by the Ministry of Environment and Regional Development, while in Estonia the Ministry of Finance is in charge. In Germany the responsibility is delegated to the Federal Maritime and Hydrographic Agency (part of the Federal Ministry of Transport and Digital Infrastructure), while in Sweden it is the Swedish Agency for Marine and Water Management (under the Ministry of Environment and Energy) and in Denmark the Danish Maritime Agency (under the Ministry of Business and Growth).
} 
5. Difficulties to involve certain types of stakeholders. Although many stakeholders initially do not see many benefits of participating in MSP, some groups appear to be especially difficult to mobilise at present: regional and local authorities (especially politicians), highly differentiated sectors (e.g. tourism), sectors with little trust in MSP (often the fisheries sector), and the general public.

Both the BaltSpace and the Baltic SCOPE projects include evidence of multilevel governance issues. There is a need to think in terms of multilevel governance and related challenges (Marks 1993; Hooghe and Marks 2003; Jessop 2003; Piattoni 2010; Kull 2014), ${ }^{7}$ as MSP has to reach across jurisdictional boundaries and administrative levels and include non-governmental actors. According to legislation, MSP is a top-down exercise; at the same time, it has to rely on endogenous, place-based knowledge and needs to include the corresponding knowledge bearers.

Summing up, with MSP at an initial stage of development in the BSR, there is a need to (1) raise awareness and understanding among marine users, authority stakeholders and the public at large; (2) develop capacity for participatory processes among responsible authorities and stakeholders; (3) develop a better understanding of MSP processes in various BSR countries and (4) evaluate and compare MSP settings and processes across borders. A framework to systematically and group specifically analyse participation in MSP in transboundary settings can be useful to develop participation further, also in national contexts.

\section{$4 \quad$ Towards a Framework for Analysing Participation in MSP in Transboundary Settings}

Based on the earlier theoretical analysis and the current situation in the Baltic, we now move towards a framework that could be used to analyse and develop participation in MSP in transboundary settings. We suggest the following dimensions for consideration in such a framework:

(1) reasons and purpose of involvement (why);

(2) depth and breadth of involvement (who);

\footnotetext{
${ }^{7}$ For example, coordination challenges (e.g. Bache et al. 2012; Kull and Tatar 2015) which require careful consideration of how, why and when to include different types of actors.
} 
(3) intensity of involvement and influence in relation to roles (how much); and

(4) methods, timing and frequency of involvement (how, when, how often).

\subsection{Reasons and Purpose of Involvement}

As set out above, it is crucial for the organisers of the MSP processes to better understand various purposes and forms of stakeholder participation. Only when the objectives are clearly defined is it possible to decide who should be involved in the process and what tools would best facilitate this involvement (e.g., Reed 2008; NRC 2008). The answer to "why" thus influences "who" and "what"; answering all three is necessary for MSP that is legitimate, widely accepted, open to community and sector values and priorities, and empowering to the whole spectrum of stakeholders.

Purpose-wise, there are two main types of participation: instrumental and transformative. Instrumental participation in MSP aims to enhance the efficiency of the planning processes and their outcomes through proportionate allocation of marine space or other marine resources and mitigation of existing or foreseen conflicts (Stirling 2008). Transformative participation focuses on the process of public communication and reasoning, so that the outcomes of the process are relatively less important compared to giving a voice to society. Transformative participation aims to involve all interested and affected groups and individuals and often attempts to challenge existing relations of power (Jansen et al. 1998; NRC 2008; Stirling 2008).

Both types of participation have to fulfil three basic functions (1) improving the quality of decisions and plans, (2) enhancing legitimacy and (3) capacity building (NRC 2008). Evidently, (1) is vital for instrumental, while (2) and (3) are central for transformative participation.

Importantly, the purpose of participation and the expectations of planners and stakeholders can change throughout a planning process, requiring the who and the how to be adapted as well.

\subsection{Depth and Breadth of Involvement}

Participants in MSP are usually persons, organisations and groups affected by the plan. Apart from breadth and depth, it is also the interrelationships among participants and in relation to the plan that matter. 
Empirical results from the Baltic indicate many different types of stakeholders and a need for a highly differentiated approach to different groups and subgroups (Morf et al. forthcoming). Based on roles and needs at least four main groups need to be involved: (1) authority stakeholders from different levels (often with special mandates and rights), (2) specific stakeholder or user groups related to marine interests, (3) the public at large (a diffuse group, but usually with participatory rights) and (4) stakeholders from across the border (where rights and mandates are less clear). Even within one user group there can be considerable variety (e.g. fishers: vessel size, target species, gear types, harbours), and views and needs can differ considerably. Planners therefore need to avoid over-simplification.

These different types of participants have varying positions, interests, values and basic needs to account for-with the latter important for long-term conflict management but often difficult to address (see Morf 2006). Double- and possibly triple-loop learning ${ }^{8}$ is required across groups. For this to take place on equal terms, differences in power need to be taken account of, resulting in a differentiated approach to awareness raising, empowerment and participation methods. Lastly, political decision-makers still need to be mobilised and involved more, as they play important roles both for legitimacy and to dispatch the necessary resources for MSP.

\subsection{Intensity of Involvement and Influence in Relation to Roles}

In terms of how much influence is exerted by different stakeholders, it is important to consider direct and indirect representation and who has what mandate. MSP processes imply both representative and direct participation of stakeholders (e.g. participation by writing letters or coming to a hearing). For efficiency reasons, however, also in the Baltic, often only representatives of important stakeholders are actively invited to more interactive forms (e.g. advisory boards, steering groups, workshops).

Questions regarding representation need to be linked to consideration of the intensity of involvement and the influence that can and should be exerted by different stakeholders. Not everybody needs to have decision-making power about everything for a process to be considered legitimate and leading

\footnotetext{
${ }^{8}$ Double-loop learning questions views and goals and leads to different ways of framing a situation (questioning the rules and thinking out of the box). Triple-loop learning asks questions about how we learn, for example, by discussing the dynamics of a meeting, what learning was produced and how it was produced, see also Hurlbert and Gupta (2015).
} 
to well-informed decisions. Equally, not everyone may need to be involved at the same level of intensity at all times. MSP often includes a mix of different forms and intensities of participation depending on the situation, the purpose of the process, and the needs of the actors involved. Moreover, the distribution of responsibilities and roles varies, impacting on the influence participants can have on process and outcomes. Often, actors with formal roles have more influence than others (such as veto rights); it is common that planning authorities are orchestrating participation and have both facilitator and decision-making roles based on sector-specific legislation.

The setting also influences possibilities for exerting influence: In transboundary MSP, participation is likely to be less intense and influential than what might be possible in domestic processes. Involvement are more likely to be less interactive and on a strategic level rather than affecting operational planning content.

Overall, participants' activities could include (1) contributing to problem definition and conflict mapping, (2) providing knowledge for creating planning evidence, (3) proposals/views on how and when to use certain areas, (4) proposals/views on what needs to be protected and how, (5) proposals on how the own user group could contribute to the implementation of the plan, (6) contributions to monitoring and evaluation and (7) criticising and giving input on the process and actively contributing to making it more inclusive and transparent. Unless stakeholders are involved at an early stage of a planning process, or the whole process is open and reactive to their input, there is a risk that stakeholder participation is limited to basic instrumental (or even functional/tokenist) purposes.

\subsection{Facilitating Participation}

In addition to the principles set out above, methods of facilitating participation are an important added consideration. Currently, there is no standardised procedure helping planners to select suitable participation techniques (Luyet et al. 2012). Planners will usually need to follow existing legislation and consider other factors, such as available resources, including time, facilitation experience and capacity of both the planning team and participants. They also need to take into account the differences in knowledge, formal education and social status, cultural and social norms, experiences in similar managerial initiatives, history of relationships and power disparities (Rowe and Frewer 2000; NRC 2008; Luyet et al. 2012). Usually, whoever designs the process (perhaps with the help of experts) defines the necessary degree of involvement 
based on their knowledge, experience, feelings or expectations (Daniels et al. 1996).

There are numerous methods and techniques to stimulate interactions between planners, authorities and stakeholders. Public participation methods include (1) formalised approaches, such as referenda, public hearings, presentations, questionnaires and surveys, and periods for comments; (2) more collaborative approaches, like citizen panels, advisory committees, citizen juries, multicriteria analysis, cognitive maps or online deliberations and (3) techniques for which high engagement is central, such as joint fact-finding, policy dialogues, negotiated rulemaking, community partnerships or consensus conferences (Rowe and Frewer 2000; Lynam et al. 2007; NRC 2008; Luyet et al. 2012). None of these methods are by definition better than the other, although of course some are more suitable for specific positions on the MSP participation ladder. The assessment or usefulness of these tools depends on the process evaluation criteria (Rowe and Frewer 2000; Oels 2006; Blackstock et al. 2007; Luyet et al. 2012), which in turn are dependent on the formulation of policy and participation goals.

\subsection{Towards a Combined Ladder of Participation in MSP}

Based on the previous sections, we now present a combined ladder to analyse participation in transboundary MSP contexts (Table 10.2). Many dimensions could have been included, resulting in very complex constructs. To keep the framework simple, our focus is on elements that can readily be observed. We concentrate on (1) the degree of power sharing (visible, e.g. in the distribution of formal and informal roles), (2) the intensity of communication and learning (e.g. one-way or two-way, listening and acknowledging and the potential for double and triple loop learning) and (3) responsibilities for concrete planning and management tasks (functions). All three increase from the bottom to the top tiers of the ladder. These dimensions are necessarily interlinked and can vary depending on each MSP context. In principle, each step on the ladder could also be associated with a number of techniques for participation, depending on the desired purpose and type of communication and learning (not presented in detail here). We also formulate our ladder to reflect the context of current MSP constraints-for example, legal requirements that demand a dedicated authority formally in charge of the MSP process.

The ladder is structured along the degree of influence that can be exerted and includes the intensity of communication and responsibilities (left-hand column). The other two columns specify what this implies from the perspec- 
Table 10.2 A ladder or stairway of MSP participation. Steps build on each other and do not reflect the "dark" manipulative and technocratic sides of participation

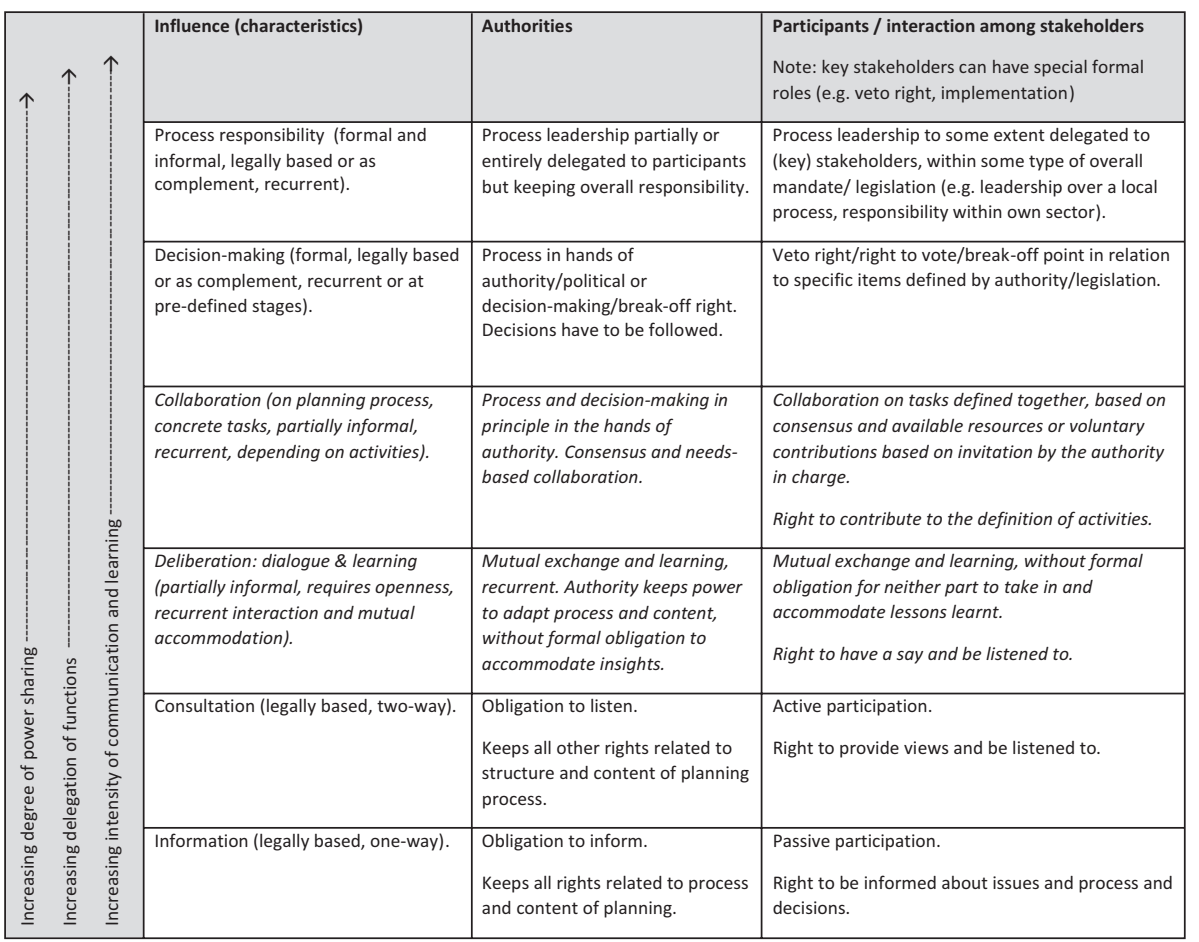

tive of responsible authorities and participants. The term "ladder" should not be understood as linear, nor does it imply that one step is seen as superior over another. Rather, different steps might be complementary or need to differ based on the specific planning stage and context.

Lastly, the ladder should really be understood as three-dimensional, as the steps in italics are not part of the power dimension (based on specified roles) but belong to a more open and concurrent interaction and deliberation dimension with more shifting roles that can be imagined as superimposed on the power dimension. We also emphasise that this ladder does not include the "dark" or manipulative or technocratic side of participation.

The provision of information has become a common basic step in national and transnational MSP processes, expected both by authorities and by stakeholders. Usually, the process is directed by the authorities in terms of both content and spread. Rather than information as such, the issue is whether the information reaches all relevant stakeholders. This is a particular concern in early stage MSP and especially in transboundary MSP when awareness of MSP and its requirements is still limited. Language can act as an added bar- 
rier: Examples from the Baltic (e.g. Germany and Poland) highlight a need to translate plans into other languages and to find ways of approaching stakeholders in the other country.

Consultation has also become a standard feature of MSP in most countries due to legal requirements. Typical examples are the consultation processes recently carried out on draft MSP plans in Germany, Poland and other Baltic countries, involving varying ranges of stakeholders. For authorities, this brings with it the obligation to take into account the views put forward by stakeholders, while stakeholders have a right to be listened to. The planning process itself, however, including authority over content and structure, is still in the hands of the authority.

Deliberation broadens the scope of consultation and any subsequent steps on the ladder, although the authority retains the power to adapt the process and content of MSP. There is no formal obligation to accommodate any insights gained from deliberation. This step is, therefore, not directly related to power but more to the degree of interaction between stakeholders and opportunities offered for mutual learning. An example from the Baltic are stakeholder workshops organised in Latvia and Lithuania as part of MSP pilot projects, which were an opportunity for different stakeholder groups to meet and exchange views to be fed back into the MSP process.

Collaboration, like deliberation, is more related to the degree of interaction (and functions of participation), although power is shifting. The power over the process remains in the hands of the authority in charge, but participants may have a right to contribute to defining activities, at least during some stages of the process. Collaboration can be formal or informal and is usually based on available resources or voluntary contributions made on the invitation of the authority in charge (e.g. with limited planning resources, Denmark might need to rely on this).

Decision-making is another form of engagement, where the process is in the hands of the authority but there is a veto right for stakeholders. This gives stakeholders the power to break off a process, albeit still in line with a framework set out by the authority or legislation. For example, in Poland and Latvia, municipalities have much stronger rights, which can be used for this purpose.

Process responsibility, lastly, implies that process leadership has been partially or entirely delegated to participants. The authority retains overall responsibility for the process as defined by its legal mandate. Here, process leadership may be delegated to stakeholders with a particular mandate. Examples can be delegated leadership over a local/sector process, such as in nested approaches to MSP with national and lower-level plans (e.g. Germany). 
The ladder is designed as an analytical tool that can reveal the position of certain processes or stakeholders along the three selected dimensions. As such, it does not imply a quality judgement of participation. Each step on the ladder has its justifications and none is automatically inferior to anotheralthough each can be done well and successfully or badly and unsuccessfully.

We note that irrespective of the desired intensity, participation does not happen automatically. Even the provision of information requires active and target group-specific facilitation. An additional question is therefore what methods can be employed to successfully take each desired step. As stated above, suitable methods could easily be added to each step of the ladder.

Another aspect that is often overlooked concerns the timing of participation. If the timing of participation in the planning cycle is bad and the scope for stakeholder input is communicated wrongly, even the best participative process may not be able to achieve the desired outcomes. For example, the kind of input that can be provided by participants and the possibilities to affect outcomes usually decrease as planning proceeds. Each row and step on the ladder would therefore ideally be complemented further by the aspects of methods and timing.

\section{$5 \quad$ Conclusions and Outlook}

Based on theoretical reflections and empirical insights from the Baltic Sea, this chapter has attempted to distil key dimensions of participation to develop a framework for analysing and comparing participation in MSP in transboundary settings. The framework suggested should be understood as complementary to other relevant ladders, namely:

- The split ladder by Hurlbert and Gupta (2015), which can assist overall diagnosis, but may be difficult to use for finer analysis in cross-border MSP settings.

- The ladder by Kidd and McGowan (2013), which emphasises cross-border collaboration but does not explicitly analyse the roles and influence of individual stakeholders.

- The ladder by Twomey and O'Mahony (2018) which helps to analyse interaction, even if it is less distinctive in relation to rights and roles of specific stakeholder types and subgroups.

Testing and further refining of the proposed concept are required to facilitate both research-based analysis and practical comparison of participatory 
approaches. A possible future development might be to design a "climbing wall" of parallel ladders for different types of MSP stakeholders, helping to compare the many different dimensions of stakeholder participation in MSP. More work is also required on how to include important time and methodological dimensions that have not yet been developed here.

In practice, as MSP in the Exclusive Economic Zone is a top-down exercise, usually mandated at national or regional levels, participation in MSP will likely be based on formal components. Still, even highly formal types of participation (such as consultation) can benefit from enhanced interaction and mutual learning across levels and sectors, illustrated by the dimensions of double and triple-loop learning. Moreover, top-down driven processes also need to engage with bottom-up processes (e.g. local MSP projects, scenarios, mapping exercises), meaning formal approaches need to give room to informal ones in their process design and vice versa. At the same time, expectation management is important, and authorities should be transparent with respect to the available headroom in designing and implementing participatory processes including rules for decision-making. Here, the ladders could help define the respective status of informal and formal processes and set out ways for how they could enhance each other.

Cross-border and transboundary MSP implies a need to involve neighbouring authorities in MSP processes, but also non-authority stakeholders from adjoining countries. In the BSR at least, processes for doing so have not yet been developed; this could be supported by a more analytical use of the ladder. The ladder could also be helpful in identifying the current national state of play of MSP and-especially in countries where MSP is in the initial stages - needs for capacity building and awareness raising. In some countries coastal spatial planning has had decades of practice (e.g. Sweden in municipal planning, Finnish regional planning or the German Federal States), but, unless a way is found to analyse and compare these approaches, available practices and experiences will not necessarily be easy to incorporate and learn from. This does not imply benchmarking, which may be difficult, as MSP is multidimensional and different countries have different systems and views of participation (e.g. some countries will be striving for more collaborative approaches than others). At the same time, cross-comparison and evaluating the benefits of different types of participation on the basis of set criteria can promote learning from each other. As MSP continues to develop as a new professional field, there is a need to remain attentive to the different purposes of participation and to make constructive use of analytical dimensions when organising and analysing participation in MSP 
Acknowledgements The development of the chapter took place under the project "Economy of maritime space" funded by the Polish National Science Centre. The Open Access fee of this chapter was provided by this project. This work was also supported by the BONUS BALTSPACE project, which has received funding from BONUS (Art 185), funded jointly from the EU's Seventh Programme for research, technological development and demonstration, and from Baltic Sea national funding institutions. Furthermore, research by Nordregio, within the authority-driven MSP project Baltic SCOPE (Towards coherence and cross-border solutions in Maritime Spatial Planning; 2015-17), co-financed by the European Maritime and Fisheries Fund and the project partners (national authorities and regional organisations) provided important results. We warmly thank our informants and colleagues in these projects, documented in among others Kull et al. (2017) and Morf et al. (forthcoming).

\section{References}

Armitage, D., Marschke, M., \& Plummer, D. (2008). Adaptive Co-management and the Paradox of Learning. Global Environmental Change, 18, 86-98.

Arnstein, S. R. (1969). A Ladder of Citizen Participation. Journal of the American Institute of Planners, 35, 216-224.

Bache, I., Bartle, I., \& Flinders, M. (2012). Unravelling Multilevel Governance: Beyond the Binary Divide. Paper Delivered at the Workshop "Governance and Participation Research". University of Sheffield, June 6.

Berkes, F. (1994). Co-management: Bridging the Two Solitudes. Northern Perspectives, 22, 18-20.

Berkes, F. (2009). Evolution of Co-management: Role of Knowledge Generation, Bridging Organizations and Social Learning. Journal of Environmental Management, 90, 1692-1702.

Bingham, L., Nabatchi, T., \& O'Leary, R. (2005). The New Governance: Practices and Processes for Stakeholder and Citizen Participation in the Work of Government. Public Administration Review, 65, 547-558.

Bishop, P., \& Davis, G. (2002). Mapping Public Participation in Policy Choices. Australian Journal of Public Administration, 61, 14-29.

Blackstock, K. L., Kelly, G. J., \& Horsey, B. L. (2007). Developing and Applying a Framework to Evaluate Participatory Research for Sustainability. Ecological Economics, 60, 726-742.

Borrini-Feyerabend, G., Pimbert, M., Farvar, M. T., Kothari, A., \& Renard, Y. (2004). Sharing Power. Learning by Doing in Co-management of Natural Resources Throughout the World. Tehran: IIED and IUCN/CEESP/CMWG, Cenesta.

Bryson, J. M., Quick, K. S., Slotterback, C. S., \& Crosby, B. C. (2012). Designing Public Participation Processes. Public Administration Review, 73, 23-34.

Carlsson, L., \& Berkes, F. (2005). Co-management: Concepts and Methodological Implications. Journal of Environmental Management, 75, 65-76. 
Collins, K., \& Ison, R. (2009). Jumping Off Arnstein's Ladder: Social Learning as a New Policy Paradigm for Climate Change Adaptation. Environmental Policy and Governance, 19, 358-373.

Daniels, S. E., Lawrence, R. L., \& Alig, R. J. (1996). Decision-Making and Ecosystem-Based Management: Applying the Vroom-Yetton Model to Public Participation Strategy. Environmental Impact Assessment Review, 16, 13-30.

Dyrberg, T. B. (1997). The Circular Structure of Power: Politics, Identity, Community. New York: Verso.

Fainstein, S. S., \& Fainstein, N. (1996). City Planning and Political Values: An Updated View. In S. Campbell \& S. S. Fainstein (Eds.), Readings in Planning Theory (pp. 265-287). Oxford: Blackwell.

Foucault, M. (1980, May). Power/Knowledge. Selected Interviews and Other Writings, 1972-1977 (1st ed.). Harvester Press.

HELCOM-VASAB. (2010). Baltic Sea Broad-Scale Maritime Spatial Planning Principles. Retrieved from http://www.helcom.fi/action-areas/maritime-spatialplanning/msp-principles.

HELCOM-VASAB. (2016). Guidelines on Transboundary Consultations, Public Participation and Co-operation. Adopted by the MSP Working Group in June 2016. Retrieved from http://www.helcom.fi/Documents/Action\%20areas/ Maritime $\% 20$ spatial\%20planning/Guidelines\%20on\%20transboundary\%20 consultations $\% 20$ public $\% 20$ participation $\% 20$ and $\% 20$ co-operation $\% 20$ June\%202016.pdf.

Hooghe, L., \& Marks, G. (2003). Unraveling the Central State, but How?-Types of Multi-level Governance. American Political Science Review, 97, 233-243.

Hurlbert, M., \& Gupta, J. (2015). The Split Ladder of Participation: A Diagnostic, Strategic, and Evaluation Tool to Assess When Participation Is Necessary. Environmental Science \& Policy, 50, 100-113.

Jansen, F. M., Jensen, P. M., Vindig, D., Ellemann-Jensen, H., \& Steffen, L. C. (1998). "We Are Strong Enough": Participatory Development in Practice. Copenhagen: DanChurchAid.

Janßen, H., Varjopuro, R., Luttmann, A., Morf, A., \& Nieminen, H. (2018). Imbalances in Interaction for Transboundary Marine Spatial Planning: Insights from the Baltic Sea Region. Ocean and Coastal Management, 161C, 201-210.

Jentoft, S., \& Chuenpagdee, R. (2009). Fisheries and Coastal Governance as a Wicked Problem. Marine Policy, 33, 553-560.

Jessop, R. (2003). Governance, Governance Failure, and Metagovernance. Paper Presented at an International Seminar Held at the Università della Calabria, November 21-23.

Kidd, S., \& McGowan, L. (2013). Constructing a Ladder of Transnational Partnership Working in Support of Marine Spatial Planning: Thoughts from the Irish Sea. Journal of Environmental Management, 126, 63-71.

Kull, M. (2014). European Integration and Rural Development-Actors, Institutions and Power. London: Routledge. 
Kull, M., \& Tatar, M. (2015). Multi-level Governance in a Small State-A Study on Involvement, Participation, Partnership, and Subsidiarity. Regional \& Federal Studies. https://doi.org/10.1080/13597566.2015.1023298.

Kull, M., Moodie, J., Giacometti, A., \& Morf, A. (2017). Lessons Learned: Obstacles and Enablers When Tackling the Challenges of Cross-Border Maritime Spatial Planning — Experiences from Baltic SCOPE. Stockholm: Espoo and GothenburgBaltic SCOPE. Retrieved from http://www.balticscope.eu/content/ uploads/2015/07/BalticScope_LL_WWW.pdf.

Luyet, V., Schlaepfer, R., Parlange, M. B., \& Buttler, A. (2012). A Framework to Implement Stakeholder Participation in Environmental Projects. Journal of Environmental Management, 111, 213-219.

Lynam, T., de Jong, W., Sheil, D., Kusumanto, T., \& Evans, K. (2007). A Review of Tools for Incorporating Community Knowledge, Preferences, and Values into Decision Making in Natural Resources Management. Ecology and Society, 12(1), 5. Marks, G. (1993). Structural Policy and Multilevel Governance in the EC. In A. Cafruny \& G. Rosenthal (Eds.), The State of the European Community (pp. 391-411). New York: Longman.

Matczak, M., Przedrzymirska, J., Zaucha, J., \& Schultz-Zehden, A. (2014). Handbook on Multi-level Consultations in MSP. PartSeaPate. Retrieved from http://www.partiseapate.eu/wp-content/uploads/2014/09/PartiSEApate_handbook-on-multilevel-consultations-in-MSP.pdf.

Morf, A. (2006). Participation and Planning in the Management of Coastal Resource Conflicts: Case Studies in West Swedish Municipalities. Ph.D. Dissertation. Gothenburg: School of Global Studies, University of Gothenburg. ISBN 91-975290-3-6.

Morf, A., Strand, H., Gee, K., Gilek, M., Janßen, H., Hassler, B., Luttmann, A., Piwowarczyk, J., Saunders, F., Stalmokaite, I., \& Zaucha, J. (forthcoming). BONUS BALTSPACE Deliverable D2.3: Exploring Possibilities and Challenges for Stakeholder Integration in MSP. Swedish Institute for the Marine Environment Report Series. Gothenburg: Swedish Institute for the Marine Environment, University of Gothenburg.

NRC (National Research Council). (2008). Public Participation in Environmental Assessment and Decision Making. Washington, DC: The National Academies Press.

Oels, A. (2006). Evaluating Stakeholder Dialogues. In S. Stoll-Kleemann \& M. Welp (Eds.), Stakeholder Dialogues in Natural Resources Management. Theory and Practice (pp. 117-151). Berlin Heidelberg: Springer-Verlag.

Piattoni, S. (2010). The Theory of Multi-level Governance: Conceptual, Empirical, and Normative Challenges. Oxford: Oxford University Press.

Pomeroy, R., \& Berkes, F. (1997). Two to Tango: The Role of Government in Fisheries Co-management. Marine Policy, 21, 465-480.

Pretty, J. (1995). Participatory Learning for Sustainable Agriculture. World Development, 23, 1247-1263.

Quick, S., \& Bryson, J. (2016). Public Participation. In C. Ansell \& J. Torfing (Eds.), Handbook on Theories of Governance. Cheltenham: Edward Elgar. 
Reed, M. S. (2008). Stakeholder Participation for Environmental Management: A Literature Review. Biological Conservation, 141, 2417-2431.

Rittel, H., \& Webber, M. (1973). Dilemmas in a General Theory of Planning. Policy Sciences, 4, 155-169. Elsevier Scientific Publishing Company, Inc.: Amsterdam. [Reprinted in] Cross, N. (Ed.), Developments in Design Methodology. 1984. J. Wiley \& Sons: Chichester, pp. 135-144.

Rowe, G., \& Frewer, L. (2000). Public Participation Methods: A Framework for Evaluation in Science. Technology and Human Values, 25, 3-29.

Sandercock, L. (1998). The Death of Modernist Planning: Radical Praxis for a Postmodern Age. In M. Douglass \& J. Friedmann (Eds.), Cities for Citizens: Planning and the Rise of Civil Society in a Global Age (pp. 163-184). Chichester and New York: John Wiley and Sons.

Selle, K. (Ed.). (1996). Planung und Kommunikation: Gestaltung von Planungsprozessen in Quartier, Stadt und Landschaft: Grundlagen, Methoden, Praxiserfahrungen. Wiesbaden und Berlin: Bauverlag.

Stirling, A. (2008). "Opening Up" and "Closing Down". Power, Participation, and Pluralism in the Social Appraisal of Technology. Science, Technology, \& Human Values, 33, 262-294.

Stoker, G. (1998). Governance as Theory: Five Propositions. International Social Science Journal, 50, 17-28.

Twomey, S., \& O'Mahony, C. (2018). Stakeholder Processes in Marine Spatial Planning: Ambitions and Realities from the European Atlantic Experience. In J. Zaucha \& K. Gee (Eds.), Marine Spatial Planning-Past, Present, Future. Palgrave Macmillan.

Zaucha, J. (2014a). Sea Basin Maritime Spatial Planning: A Case Study of the Baltic Sea Region and Poland. Marine Policy, 50, 34-45.

Zaucha, J. (2014b). The Key to Governing the Fragile Baltic Sea. Maritime Spatial Planning in the Baltic Sea Region and Way Forward. Riga: VASAB Secretariat.

Open Access This chapter is licensed under the terms of the Creative Commons Attribution 4.0 International License (http://creativecommons.org/licenses/by/4.0/), which permits use, sharing, adaptation, distribution and reproduction in any medium or format, as long as you give appropriate credit to the original author(s) and the source, provide a link to the Creative Commons licence and indicate if changes were made.

The images or other third party material in this chapter are included in the chapter's Creative Commons licence, unless indicated otherwise in a credit line to the material. If material is not included in the chapter's Creative Commons licence and your intended use is not permitted by statutory regulation or exceeds the permitted use, you will need to obtain permission directly from the copyright holder. 